Article

\title{
Facing Precarious Rights and Resisting EU 'Migration Management': South European Migrant Struggles in Berlin
}

\author{
Celia Bouali \\ Department of Social Sciences, Faculty of Humanities and Social Sciences, Humboldt University of Berlin, 10117 Berlin, \\ Germany; E-Mail: celia.bouali@cms.hu-berlin.de
}

Submitted: 30 November 2017 | Accepted: 6 March 2018 | Published: 29 March 2018

\begin{abstract}
In this article, I trace struggles regarding EU internal mobility and migrant labour as they emerge in the mobilization of South European migrants in Berlin. The effects of the 2007-2008 financial crisis and European austerity politics have reoriented migration flows within the EU, increasing South-to-North migration with Germany as a prime destination. German public discourse on the matter reveals a view on (EU) migration that focuses on its economic 'usefulness' and tries to regulate it accordingly. EU citizenship turns out to be a key instrument of such EU internal 'migration management'. The emergence of migrant activist groups, however, hints at another force at play. In their fight for social rights and better working conditions, migrant activists show they will not allow themselves to be easily 'managed' into precarious 'productivity'. Against this background, I argue that EU internal mobility is a field of struggle where attempts to control migrant labour clash with moments of autonomy and resistance. My aim is to explore this field from a migration perspective, analysing rationales of EU 'migration management' and their impact on migrants' lives as well as investigating the strategies that migrants develop in response. Based on an analysis of EU legislation and interviews with Italian activists in Berlin, I trace conflicts around EU internal mobility and migrant labour. Against the background of critical migration studies, I analyse EU internal 'migration management', especially regarding the role of EU citizenship. Then, I look at EU migrant struggles in Berlin through the lens of autonomy of migration, drawing on the example of the Italian activist group Berlin Migrant Strikers.
\end{abstract}

\section{Keywords}

autonomy of migration; border regime; differential inclusion; migrant labour; migration management; migrant struggles

\section{Issue}

This article is part of the issue "The Transformative Forces of Migration: Refugees and the Re-Configuration of Migration Societies", edited by Ulrike Hamann and Gökçe Yurdakul (Humboldt University of Berlin, Germany).

(C) 2018 by the author; licensee Cogitatio (Lisbon, Portugal). This article is licensed under a Creative Commons Attribution 4.0 International License (CC BY).

\section{Introduction}

The effects of the 2007-2008 financial crisis and European austerity politics have reoriented migration flows within the EU, increasing South-to-North migration with Germany as a prime destination (IMIS \& bpb, 2013, p. 3). ${ }^{1}$ The various narratives of the German public discourse on the subject, for instance praise of the 'brain gain' or the 'fear' of 'benefit tourism', boil down to a view on (EU) migration that focuses on its economic 'useful- ness' and tries to regulate and filter it accordingly (Riedner, 2015). EU citizenship, promising equality and freedom of movement among EU citizens, turns out to be a key instrument of such EU internal 'migration management'. The emergence of (South European) migrant activist groups in Germany, however, hints at another force at play. In their demands for social rights and better working conditions, migrant activists show they will not allow themselves to be easily 'managed' into precarious 'productivity'.

\footnotetext{
${ }^{1}$ While this article deals with South-to-North migration within the EU following the 2007-2008 financial crisis and European austerity politics, this is of course neither the only nor the main form of migration occurring within the EU. EU internal East-to-West migration is ongoing and often centre-stage when it comes to debates on EU 'migration management' (Schoenes \& Schultes, 2014). This goes particularly for migrants from Bulgaria and Romania whose freedom of movement within the EU is often called into question against the background of racist narratives (Schoenes \& Schultes, 2014).
} 
Against this background, I argue that EU internal mobility is a field of struggle where attempts to control migrant labour clash with moments of autonomy (Bojadžijev \& Karakayalı, 2007) and resistance. My intention is to explore this field from the perspective of migration, analysing rationales of EU 'migration management' and their impact on migrant lives as well as investigating strategies migrants develop with regard to it. I seek to offer preliminary results for future research. My focus lies with the specific context of South European, particularly Italian, migration to Germany against the background of European austerity politics and the dynamics between Germany and Southern Europe. How does EU 'migration management' function in this context and how do migrant (activist) practices relate to it?

Based on an analysis of EU legislation and semistructured interviews with Italian migrant activists in Berlin, I explore conflicts around EU internal mobility and migrant labour. Drawing on critical migration research, I start with a brief introduction on labour mobility in the context of changing border regimes, which informs my analysis of EU internal 'migration management' and EU citizenship. Finally, I look at EU migrant struggles in Berlin through the lens of autonomy of migration, drawing on the example of the Italian activist group Berlin Migrant Strikers.

\section{Precarious Rights: EU 'Migration Management'}

\subsection{Migrant Labour and Border Regimes}

This article is based on an understanding of migration as a key factor in capitalistic development, especially regarding the control and exploitation of labour (Mezzadra, 2006; Moulier-Boutang, 1998). Drawing on critical migration research, I conceptualize migration as taking place in a field of struggle where moments of autonomy and attempts to control and regulate migration clash, interact and bring about complex, ever-changing border regimes (Casas-Cortes et al., 2014, p. 69). In the context of multiplying and increasingly heterogeneous borders (CasasCortes et al., 2014, p. 57; Mezzadra, 2015, p. 128), critical migration scholars observe a multiplication of status' and social positions of migrants (Casas-Cortes et al., 2014 , p. 79). Using the concept of differential inclusion, they describe processes that instead of bringing about clear-cut inclusion or exclusion, produce a stratification of rights, social positions, and belonging (Mezzadra \& Neilson, 2012, p. 67). This differential system of filtering and segmentation, which functions as a measure of hierarchisation and control (Mezzadra \& Neilson, 2008, p. 7), is linked to specific forms of 'migration management' (Hess \& Kasparek, 2010, p. 17) and entangled with what Mezzadra and Neilson have described as the multiplica- tion of labour (Mezzadra, 2016, p. 40), an increasing diversification of labour regimes and positionalities.

\subsection{EU Citizenship and EU 'Migration Management'}

In this article, I look at a form of migration that due to EU citizenship, not only seems privileged but in comparison to other forms of migration completely 'deproblematized' since it is legally protected by the freedom of movement which exists for EU citizens. Since the 1990s, there has been ample scholarly debate around the emergence of EU citizenship and its implication for issues of migration:

Although its acquisition remained subordinated to the status of citizens of member states of the EU, the institution of European citizenship appeared to many scholars as the opening up of a process of de-linking citizenship from the principle of nationality that could potentially run parallel to the recognition of migrants' rights independently from their citizenship or even migration status. (Mezzadra, 2015, p. 132)

In reality, however, it turned out to be different with EU citizenship largely consolidating the differences between EU citizens and 'the rest'. Furthermore, the emergence of EU citizenship has been accompanied by intensified border and migration control as well as growing rightwing movements across Europe (Mezzadra, 2015, p. 132). Mezzadra also emphasises "that in the wake of the global crisis European citizenship has been stripped of any social and progressive meaning in the eyes of a wide majority of (not only Southern) European autochthonous populations" (Mezzadra, 2015, p. 132). He thus considers the crisis to also encompass a crisis of-specifically European-citizenship (Mezzadra, 2015, p. 133).

So how can we understand EU citizenship in the context of migration (control)? How does it relate to European border and migration regimes? How can we analyse it in the context of the multiplication of borders and labour as well as differential inclusion?

\subsubsection{Legal Framework}

EU citizenship was introduced in the context of the Treaty of Maastricht in 1992. Its current legal basis is articles 9 to 12 of the Treaty on European Union (TEU), articles 18 to 25 of the Treaty on the Functioning of the European Union (TFEU) as well as articles 39 to 46 of the EU Charter of Fundamental Rights (EUCFR) (Bux, 2017). Citizens of the member states, thereby, automatically become EU citizens, with EU citizenship functioning not as a replacement, but as an addition to national citizenship (§20 TFEU). Much like the latter, “EU citizenship refers

\footnotetext{
${ }^{2}$ Defined as attempts "to govern and manage migration, to operationalize policies of differential inclusion, and to manage the balance between the needs of labor markets, the demands for rights and in some cases citizenship, and the projection of securitization and humanitarianism on the border" (Casas-Cortes et al. 2014, p. 67 with reference to Walters, 2011). I will use this term - that was rightfully criticised for its cynicism-in single quotation marks to describe said attempt because it captures the underlying perspective on migration and migrant labour.
} 
to a relationship between the citizen and the European Union which is defined by rights, duties and political participation" (Bux, 2017). The core elements of this relationship are freedom of movement within the EU, active and passive voting rights in local elections in the place of residence in the EU as well as the right to petition and vote in the EU parliamentary elections in the country of residence ( $\$ 20 \mathrm{TFEU})$.

EU citizens' freedom of movement within the EU has its legal basis in article 3(2) TEU, article 21 as well as titles IV and V TFEU and article 45 EUCFR. The general right as established in the primary law is tied to certain conditions and concretised in the EU Directive 2004/38/EC (Voigt, 2017, p. 9). The directive states that EU citizens have the right to move freely within the EU as well as to reside for up to three months in another EU country without having to fulfil any requirements (except for a valid identity document or passport) (§4(1), §5(1), §6(1) Directive $2004 / 38 / E C)$. For stays longer than three months certain criteria have to be met: ${ }^{3} \mathrm{EU}$ citizens must either be working or "have sufficient resources and sickness insurance to ensure that they do not become a burden on the social services of the host Member State during their stay" (Marzocchi, 2017; §7 Directive 2004/38/EC). EU citizens may acquire the right to permanent residence in another EU country without further requirements "after a five-year period of uninterrupted legal residence, provided that an expulsion decision has not been enforced against them" (Marzocchi, 2017; §16(1), §21 Directive $2004 / 38 / E C)$. Furthermore, article 24 of the directive stipulates a requirement for equal treatment in comparison to 'natives' in another EU country, for instance regarding migrants' involvement in the labour market. Restrictions on stays and the freedom of movement such as the expulsion of EU citizens from other EU countries or bans on staying in another member state are possible. According to the directive, such measures may be taken only based on concerns regarding public policy, public security, or public health (Marzocchi, 2017). The directive also states that the measures must not be "taken on economic grounds, comply with the proportionality principle and...[be] based on personal conduct" (Marzocchi, 2017).

\subsubsection{Underlying Rationales}

As we have seen, primary law establishes EU citizenship and with it freedom of movement within the EU. It provides such rights, however, under conditions and regulations which are in turn elaborated on in secondary law, i.e., Directive 2004/38/EC. There, we note the importance of economic criteria invoked regarding EU citizens' freedom of movement. These economic criteria, and on a broader level the range of rights EU citizenship entails (as well as their preconditions), have been subject to controversy. The European Court of Justice (ECJ) has played an important role in defining the 'content' of EU citizenship, the rights it entails and its relation to certain (economic) criteria (Riedner, 2017, pp. 99-101). While between the late 1990s and the early 2010s its judgements seemed to pave the way for EU citizenship as 'social citizenship' (entailing welfare access among other things) (Buckel, 2013), in recent cases the tide has turned. Against the background of debates on 'benefit tourism' (see Jobelius \& Stoiciu, 2014), the ECJ has validated national (particularly German) legislation that (increasingly) limits EU citizens' access to welfare and confirmed it does in fact not contradict EU legislation.

In the case of Elisabeta Dano and her son, the ECJ ruled that the exclusion of "economically inactive" EU citizens without sufficient resources "from entitlement to certain 'special non-contributory cash benefits'" does not contradict EU legislation insofar as those citizens "do not have a right of residence under Directive 2004/38 in the host Member State" (Case C-333/13 Dano vs. Jobcenter Leipzig, 2014, para. 93). In the case of Nazifa Alimanovic and her family, that possibility of exclusion "from entitlement to certain 'special non-contributory cash benefits'" was extended to EU citizens who reside in another member state solely for the purpose of finding work (Case C-67/14 Alimanovic vs. Jobcenter Berlin Neukölln, 2015). In the case of Jovanna García-Nieto and her family, the ECJ ruled that EU citizens who are not working may be excluded "from entitlement to certain 'special non-contributory cash benefits'" during the first three months of their stay in another member state (Case C-299/14 García-Nieto and Others vs. Jobcenter Kreis Recklinghausen, 2016).

In short, the ECJ ruling implies that EU citizens' freedom of movement is neither automatic nor unconditional, their (equal) access to social rights is contingent on their right of residence, which in turn is linked to economic pre-conditions that are up for review by the respective state agencies (Kötter, 2016, pp. 3-4; Riedner, 2017, p. 101). The result is that access to freedom of movement is contingent on economic criteria (Kötter, 2016, p. 4).

Full EU citizenship rights are available only under economic preconditions, i.e., only "economically active" EU citizens have access to social benefits, while "'unemployed persons' or 'job-seekers [with ${ }^{4}$ or] without reasonable prospects of success' forfeit their social rights and may upon individual review also lose their right to freedom of movement or even be expelled" (Riedner, 2015 , p. 18, author's translation). In other words, being 'unproductive' in the context of EU freedom of movement becomes a punishable offence. ${ }^{5}$

\footnotetext{
${ }^{3}$ It is important to note, however, that EU citizens (and their family members) always have a right of residence in other member states (even if the criteria above aren't met) unless it has officially been withdrawn in a bureaucratic procedure. Unlike third country nationals, they don't require a visa or residence permit (Voigt, 2017, p. 9). For a more detailed account of the criteria, see Voigt (2017).

${ }^{4}$ C-67/14 Jobcenter Berlin Neukölln vs Alimanovic, 2015, paras. 52-58.

${ }^{5}$ Alberti points out how in the UK even the criteria for retaining worker status become increasingly restrictive (2017, pp. 10-12). She also notes: "A paradoxical situation arises: At the same time as work becomes more precarious, uncertain, temporary, and unable to provide for one's own social reproduction, access to social protection is made dependent on the capacity to demonstrate a full worker status." (2017, p. 16).
} 
EU citizenship's limited social substance and the link between freedom of movement and being 'economically active' translates to an economization of citizenship and a precarisation of citizenship rights. This reveals a 'productivity' rationale of mobility regulation within the EU. It shows an attempt to control or 'manage' migration in a way that increases its economic 'usefulness', sanctions 'unproductiveness' and disciplines EU migrants into (precarious) wage labour (Riedner, 2015, p. 18).

In her Munich case study, Riedner illustrates the bureaucratic practice implementing this rationale:

Following the struggles of a family of EU internal migrants in Munich it shows how social institutions...turn into border guards, how the foreigners' office becomes a labour activation agency and how this fosters differential zones of equality and precarisation within the richest city of Germany. (Riedner, 2017, p. 89)

She explains how in social institutions EU citizens' requests for social benefits may trigger investigations into their residence status, turning these institutions into border guards to deter 'unwanted migration', while the foreigners' office redefines its role, becoming "a labour activation agency" (Riedner, 2017, p. 89). Riedner gives an account of a meeting she had with a department chief in the foreigners' office who explained the rationale behind their practice of sending out letters to EU citizens threatening the loss of the right of residence or expulsion. Arguing that from an "aliens law point of view" expulsions rarely "made sense" because EU citizens could almost always return immediately, their interventions were supposed to push EU migrants into work, a strategy that, according to Riedner, seems to prove effective (2017, pp. 103-104).

It is against this background that Riedner and others, such as Alberti (working on the situation in the UK) link EU 'migration management' to workfarist social and labour market policies. ${ }^{6}$ Alberti argues:

These processes appear instrumental to the 'government of mobility' in Europe..., making migrants more available, disposable, and compliant vis-a-vis their employers. It is the reproduction of a precarious workforce, with no social security cushion, under constant risk of falling into poverty, and pushed to accept lower standards that such regulatory restrictions concur to generate $(2017$, p. 16 , with reference to Leeds Solidarity Network, 2015)

EU citizenship, hence, proves to be in line with the abovementioned attempts to 'manage' migration in a profitable fashion.
In relation to European migration regimes, two aspects emerge. On one hand, as mentioned, the emergence of EU citizenship has been accompanied by increasing the hierarchy between EU citizens and 'third country nationals', a phenomenon Balibar has called "European Apartheid" (Balibar, 2003). At the same time, hierarchies amongst EU countries have been renewed and intensified, and (thus) a multiplication of statuses within EU citizenship has emerged (Nicolaus, 2014, p. 114). Not only are we witnessing "intensified debate around limitations on freedom of movement for EU citizens that mainly targets Rumanian and Bulgarian citizens, but whose concrete implementation would have decisive consequences for EU internal mobility rights per se" (Kasparek \& Tsianos, 2015, p. 5, author's translation). Following the 2007-2008 financial crisis and European austerity politics, pre-existent North-South disparities within the EU have also deepened (Nicolaus, 2014, pp. 114-115). Critical scholars from Italy draw:

Comparisons between the current North-South divide in the EU and the historic roles within the Italian economy, where structurally weak and indebted Southern regions were forced to function as a sales market and a source of cheap labour for the industrialised North. (Nicolaus, 2014, p. 115 with reference to Curcio, 2013; Rossi, 2013, author's translation)

The interplay between racist narratives problematizing certain EU internal migration, EU internal economic and political disparities and a 'productivity'-oriented EU citizenship has produced a multiplication of borders and a hierarchisation of spaces within the European Union. Through the lens of differential inclusion, we can see a stratification of rights emerging alongside multiplied status positions among EU citizens. ${ }^{7}$ (This also-but not only-becomes apparent in the attempts to 'utilize' the 'new' South-North-migrations.) EU citizenshipmuch like citizenship in general-is revealed to be a "differentiation machine" (Casas-Cortes et al., 2014, p. 84). It not only amplifies the differences between EU citizens and 'the others', its economic character and the precarisation of rights within EU citizenship also creates stratifications - on a different level-along the lines of EU internal (economic) inequalities, multiplies status positions in the context of labour and migration, and contributes to what I refer to as EU internal 'migration management'. Drawing on Thomas H. Marshall, one could argue that citizenship initially accomplishes 'equality', which then becomes the point of departure for new inequalities (Köster-Eiserfunke, Reichhold, \& Schwiertz, 2014, p. 182, with reference to Marshall, 1992, pp. 52-54).

\footnotetext{
${ }^{6}$ Social and labour market policies "based on the principle of fighting 'welfare dependency' by moving claimants into paid work through the introduction of tougher welfare conditionality and sanctions" (Alberti, 2017, p. 2).

7 These reflect the economic and political disparities between member states, citizens' financial situations and the labour market position as well as racist discourses. Alberti points out that EU citizenship is "layered" as certain "post-enlargement transitional measures", for instance, specifically targeted EU 2-citizens and the racialization of some EU citizens also comes into play $(2017$, p. 5). The question of how racist discourses and economic rationales interact within EU 'migration management' is important and should be addressed in future research.
} 


\subsection{Migrant Practices}

At the same time, perspectives such as isin's acts of citizenship (2008), which refer to political practices of citizenship beyond formal belonging and recognition, raise the question of migrant practices in the context of EU citizenship. Nicolaus, for instance, considers the increase of EU internal South-to-North migration in the context of the crisis a direct-democratic claim to EU citizens' freedom of movement (2014, p. 116). In this sense, accessing welfare benefits in Germany could also be considered an act of recovery of the social rights that (German-led) austerity politics have increasingly restrained in Southern Europe. However, it would be problematic to reduce migrant practices and struggles to 'civic' acts of rights claiming. Not only would such an idea of citizenship as an overall progressive institution, which becomes increasingly inclusive through (activist) rights claiming, mean losing sight of the concept's inherently exclusive nature (cf. Köster-Eiserfunke et al., 2014, pp. 189-190; Mezzadra, 2015, pp. 133-135). The analysis of EU citizenship shows: "Citizenship is not detached from the prevailing social circumstances but contributes to them" (KösterEiserfunke et al., 2014, p. 189, author's translation). If one's perspective focuses on 'civic' acts of rights claiming it will be difficult to fully understand migrant struggles that are not about being included into existing structures, but about challenging them. Those struggles do not necessarily refer to rights or the responsibilities of certain institutions (Köster-Eiserfunke et al., 2014, p. 192), rather they attempt to disrupt oppressive and exploitative structures and the processes that bring them about. The question of migrant practices, thus, has to be raised on a broader level while considering (EU) citizenship as an institutional framework, a repressive opponent and an opportune means all at the same time. Therefore, I will address migrant practices within, through, and against the framework of EU internal 'migration management' through EU citizenship in the following sections.

\section{Resisting 'Migration Management': An Example of EU Migrant Struggles in Berlin}

\subsection{Autonomy of Migration}

In order to underline that migration cannot be reduced to 'objective' economic or political conditions as well as to emphasize the subjective side of migration and "its ungovernable moments of freedom and excess" (Mezzadra, 2016, p.36), Moulier-Boutang, Mezzadra, and others have developed the concept of autonomy of migration (Mezzadra, 2007, p. 180). The idea is to analyse migration not only from the perspective of the institutions and structures, through which it moves, but instead think of it as interacting with them (Bojadžijev \& Karakayalı, 2007 , p. 210). First, this means acknowledging that migrants and their migration projects (built in the context of transnational spaces and networks) along with their dreams, hopes and plans attached to them are at the centre of migratory movements (Bojadžijev \& Karakayalı, 2007, pp. 210-212). This subjective side of the phenomenon cannot simply be reduced to 'objective' factors such as political or economic circumstances and exceeds attempts to control and regulate it (Mezzadra, 2007 , p. 180). This subjectivity is a situated subjectivity. "It is not a given category, but one that develops and changes with the social structures, in which action is embedded. Those structures, however, are not themselves stable, but rather they are vehicles for social contradictions, which are struggled over through and within those structures" (Bojadžijev \& Karakayalı, 2007, p. 213). The thesis of autonomy is not meant to romanticize migration or trivialize border regimes. Instead, it points to how we can only understand migration through its interaction with a concrete "historical conjuncture" of migration policy:

To speak of the movement of migration and its autonomy, thus, does not mean considering it to be separate or removed from social circumstances. Rather, migrations exist as concrete practices entangled with relations of power and dominance. (Bojadžijev \& Karakayalı, 2007, p. 214, author's translation)

Against the background of a series of misconceptions of the notion of autonomy of migration, Mezzadra suggests a reformulation of the idea that on one hand emphasizes the link between migration and exploitation while on the other hand puts migrant struggles centre stage in the analysis (Mezzadra, 2007, p. 182 with reference to Bojadžijev, Karakayalı, \& Tsianos, 2003). Emphasizing the subjective side of migration also means acknowledging its political dimension and dynamic (Scheel, 2015, pp. 4-5). "Because migrants are the ones who turn border regimes into sites of political struggle around the gradual refusal and direct appropriation of mobility and other resources" (Scheel, 2015, p. 5, author's translation).

\subsection{Berlin Migrant Strikers}

Our focus in this article lies with the 'new' Italian migration to Germany, specifically Berlin, and the conflicts that have arisen in this context. Italian migration to Germany is one example of the renewed increase in EU internal South-to-North migration following the 2007-2008 financial crisis and subsequent austerity politics in (Southern) Europe (see Faraco Blanco, Kraußlach, Montero Lange, \& Pfeffer-Hoffmann, 2015, p. 7). The socio-economic and socio-cultural composition of Italian migration to Germany makes it an interesting case to study the logic of EU 'migration management', especially in the German context and its parallel narratives of 'benefit tourism' and the 'brain gain'. In a recent study, $75,8 \%$ of Italian migrants to Germany held a university degree (Kraußlach, Duschl, \& Pfeffer-Hoffmann, 2015, p. 65). Yet, 
Italians also constitute the fourth largest group of EU migrants receiving social benefits in Germany (Bundesagentur für Arbeit, 2017). Berlin, in turn, provides an interesting framework regarding the political activism that has emerged in the context of the 'new' South European migration. Over the past years, a number of different political groups of South European migrants have appeared in Berlin's political landscape (see among others 15M Berlín, 2014; Berlin Migrant Strikers, 2017; Oficina Precaria Berlín, 2017). Partly drawing on their political experience of anti-austerity movements in Southern Europe, they address the labour, housing and living conditions of the so-called 'new migrants'. Considering their size and political positions, I do not consider these groups to be representative of South European migrants in Berlin. Rather, I consider them both an expression of and a response to societal contradictions and conflicts between EU 'migration management' and the autonomy of migration.

Considering the explorative nature of this study, I decided to draw on semi-structured interviews with EU migrant activists (as experts in the field) for data collection. Through political contacts in the Berlin left, I got in touch with the Berlin Migrant Strikers (BMS), a political group formed in 2014 by Italian activists to address (EU) migrant living and working conditions in Germany. After I presented myself, my political background as well as the research project, five BMS activists, including Giorgio Del Vecchio, agreed to an interview. The interviews were conducted in two different spaces the group was using for its political activities at the time. For the analysis (Mayring, 2015) of the collected data, I also drew on information gathered during participant observation of the BMS' meetings. For this article, Giorgio Del Vecchio offered further insight into the group's political activities.

The BMS' demographic and social composition is heterogeneous. Most activists are between the ages of 25 and 35. Some of them have lived in Berlin for years; others are recent arrivals to the city. Regarding the group's socio-economic composition, Anna, ${ }^{8}$ one of the activists, explains:

We have...a spectrum that ranges...from people who...are here to study or for research purposes, to people who have university degrees, but work in unrelated jobs or receive social benefits, to people who have no formal qualifications and find themselves in a similar situation as the previous group.

Politically, the BMS see themselves as part of an anticapitalist left. Due to the diversity of their political affiliations in Italy, however, they emphasize their antidogmatic political practice.
3.2.1. Information Politics, Self-Help and Organisation of Migrant Labour

The BMS' political activity is informed by their analysis of the specificity of EU migrant lives in Berlin. Much like the author of-and contributor(s) to-this article, they draw on and contribute to critical migration theory, and are thus part of an exchange between academic and activist knowledge (Hutta, Laister, zur Nieden \& Hess, 2013). Against this background and their experience on the ground, they consider migrant labour particularly vulnerable to precarious work, low pay and processes of dequalification, and point out the importance of (precarious) migrant labour within the German economy. Furthermore, they underscore the role the German welfare state and its institutions play in making EU migrant labour increasingly precarious (see above). As described above, the dynamic of increasing access restrictions (that never amounts to a complete exclusion, however, cf. differential inclusion) proves to be an instrument in the 'management' of EU migrant labour. Faced with these circumstances, the BMS have adapted three common political strategies to their situation: information politics, selfhelp structures and organization of migrant labour. ${ }^{9}$

Information politics initially includes self-education concerning labour market dynamics, labour rights and the German welfare system. In the second step, the activists distribute said information by producing informational material as well as by organising events and campaigns targeted towards other migrant workers and the wider public. This (counter)information, on one hand, is supposed to tackle the problem of misinformation or lack of information (regarding German bureaucracy, labour market dynamics as well as rights and possibilities for resistance). According to the activists, many migrants encounter such misinformation which renders them particularly vulnerable to bureaucratic arbitrariness and problematic working conditions. On the other hand, BMS activists view it as a sort of counter-propaganda against reactionary narratives such as that of 'benefit tourism' in Germany or the 'myth' of the 'modello tedesco' in Italy. ${ }^{10}$ The third element of their information politics, the group's social counselling service for Italian migrants, has a number of different functions. First, according to the activists, the users of the group's counselling service provide them with information regarding new strategies of their employers and German bureaucracy. Second, the users receive information about their rights and possible ways of resisting the situations they face, which, third, according to the activists, makes the counselling service an instrument of politicisation.

The BMS' second main strategy is what I have called self-help. Based on their experience of individual hardship, they built a collective support net, where resources

\footnotetext{
${ }^{8}$ The interviewees' names are anonymised.

${ }^{9}$ I will give an account of the BMS' political practices and goals as per the activists' description in order to illustrate the conflicts that arise around $E U$ 'migration management'. The data, however, does not allow for an evaluation of their effectiveness or scope.

10 Germany's 'economic success' has become a discursive feature in Italian politics and is used to legitimize labour market or social reforms that cut back labour rights or social benefits.
} 
are collectivised and made accessible to all. This includes sharing living spaces, work opportunities and organising fundraisers to help group members in financial trouble. According to the activists, it is an attempt to address the problems arising from precarious work and restricted access to social welfare in a collective and solidary manner.

The group's third main strategy is about organising migrant labour. Against the background of a lack of union activity in the sectors where migrants frequently work, the BMS support migrant labour struggles through information campaigns as well as active participation in strike pickets and demonstrations. Building on these experiences, they formed a network with other migrant activist groups that specifically supports migrant labour struggles in Berlin.

\subsubsection{Transnational Struggles and Hierarchical Spaces}

The activists consider the BMS to be a transnational migrant self-organisation that builds on the political potential of (EU) migrants as political subjects emerging from their specific material conditions of life. To them, it is the collective political antithesis to the individualising tendencies of precarious migrant labour and the conforming individualist 'I can do this'-mentalities. They consider their position as EU migrants to be a social perspective, from which they analyse societal structures and dynamics, actively intervene in those structures and dynamics as well as relate to other groups.

A common typology of 'migrants' transnational political practices" is Østergaard-Nielsen's (2003) distinction between "immigrant politics" and "homeland politics". She defines the former as "the political activities that migrants or refugees undertake to better their situation in the receiving country", while the latter refers to 'migrants' and refugees' political activities pertaining to the domestic or foreign policy of the homeland" (2003, p. 762). While the BMS' political activity addresses both the Italian and the German context, it does so in a way that exceeds those definitions. They address these contexts as interrelated and interacting within economic and political power structures, such as in the case of European austerity politics. Their status as Italian migrants in Germany relates to the role of Germany in Italian austerity politics. The framework, which binds the BMS' various contexts of action and reference, is the EU as a hierarchically structured space, which they navigate through EU citizenship. Their political activity has a transnational dimension which takes the form of a counterpart to the inter- and supranational power structures that they face.

The activists' view on their presence in Germany as well as their political activity in the country is twofold. On one hand, they consider themselves an expression of the crisis and austerity politics in Southern Europe, hence, an expression of existing power relations. On the other hand, they argue, that precisely due to the economic role of migrant labour in Germany, they have the potential to disrupt said power relations.
Our analysis of the BMS' political activities from the perspective of autonomy of migration reveals two aspects. In the context of EU 'migration management', EU citizenship constitutes an institutional framework, a repressive opponent, and an opportune means to their struggles all at the same time. 'Migration management' through EU citizenship structures their lives in Germany and frames their political project. The latter draws on the instruments at hand, but in a misappropriating way; BMS activists use EU citizens' freedom of movement not (only) in order to find work in Germany, but also to vehemently claim the social rights that they are increasingly denied both in Italy and by German as well as EU legislation. They point to fragments of a social component of EU citizenship, demand those fragments and go beyond them until they find themselves outside its 'productivity' rationale. The BMS' activism is, thus, partly located in between İsin's active and activist citizenship because their starting point is the precarity of the rights granted to them, but their demands move beyond those rights. However, the notion of citizenship from below does not do justice to their kind of political activity. They do not (just) want to claim a series of rights from a specific state or the EU. Their aim is that of disrupting capitalist rationales beyond the notion of rights. Against this background, the transnational dimension of their political activity becomes important. The BMS activists' use of EU freedom of movement generates potential for a transnationalisation of South European anti-austerity movements which could re-politicise capital-labour contradictions in the economic and political centre of Europe. Migrant struggles, thus, create the possibility of a "migration of struggles" (Casas-Cortes et al., 2014, p. 83).

If you create a part of Europe around you that suffers from austerity politics, welfare cuts, unemployment and labour reforms, which destroy workers' rights, you will face a migration that either becomes functional to you, that becomes 'productive', or that becomes a problem. (Anna, 2016)

\section{Conclusion}

In this article, I have tried to trace struggles around EU internal mobility as they emerge in the political activity of Italian migrants in Berlin. Looking at South-to-North migration following the 2007-2008 financial crisis and European austerity politics, I analysed the dynamics between EU internal 'migration management' and EU migrant struggles in Berlin.

Drawing on critical migration research, I showed how EU citizenship provides the framework for an EU internal 'migration management' that on one hand cements the disparities between EU citizens and 'the rest', while on the other hand introduces and valorises differences amongst EU citizens. In the context of 'economic' EU citizenship, EU internal freedom of movement (for EU citizens) is hinged on a diktat of 'productivity' and EU citi- 
zenship is, hence, almost 'free' of 'social substance'. This specific dynamic of 'migration management' amplifies the pre-existing tendency of migrant labour to be precarious. In the context of increasing economic and political disparities emerging from the 2007-2008 financial crisis and European austerity politics, this instrument develops a particular efficacy.

The emergence of (South European) migrant activist groups in Germany, hints at another force at play. In their demands for social rights and better working conditions, migrant activists show they will not allow themselves to be easily 'managed' into precarious 'productivity'. In the face of precarious work and increasingly restricted access to German welfare systems, the BMS make use of information politics, self-help, and organisation of migrant labour in order to strengthen migrant resistance and to intervene discursively. Their political organising is informed by theoretical concepts and reveals links between academia and activism. They consider their organisation a transnational migrant self-organisation that builds on the political potential of EU migrants as political subjects emerging from their specific material living conditions. My analysis is that the transnational dimension of their political activity mirrors the inter- and supranational power structures, which they navigate through EU citizenship. Along these lines, the BMS consider their presence and political activity in Germany both to be an expression of these power structures and to have the potential to disrupt them. We find that their political project makes use of the instruments at their disposal, but in a misappropriating way, which goes beyond their intended scope. From the perspective of the autonomy of migration, BMS activists use a 'productivity'-oriented EU citizenship in subversive ways. Their political struggles and the way they relate to South European antiausterity movements point to the possibility of migrant struggles turning into a 'migration of struggles'.

\section{Acknowledgements}

Special thanks to Giorgio Del Vecchio for his insights and his contribution to this article. Besides him, Celia Bouali wishes to thank all the Berlin Migrant Strikers, especially the interview partners, for their willingness to discuss their political work with her. Their analysis of the issue at hand was an immense contribution to this article. She would also like to thank Folashade Ajayi as well as Ulrike Hamann, Alessandro D'Arcangeli, Susanne Schultz, Thomas Schmid, Stefania Animento, Hêlîn Demirkol, Bafta Sarbo, Henrik Lebuhn, Mona Motakef, Kerima Bouali and Manfred Amedick for interesting discussions that greatly contributed to the research, their insights and comments on the manuscript and their support in general. The reviewers' and editors' comments were also greatly appreciated.

\section{Conflict of Interests}

The author declares no conflict of interests.

\section{References}

15M Berlín. (2014). Grupo de Acción Sindical (GAS). Retrieved from http://15mberlin.com/2014/05/15/ grupo-de-accion-sindical-gas

Alberti, G. (2017). The government of migration through workfare in the UK: Towards a shrinking space of mobility and social rights? movements. Journal für kritische Migrations- und Grenzregimeforschung, 3(1).

Balibar, É. (2003). We, the people of Europe? Reflections on transnational citizenship. Princeton: Princeton University Press.

Berlin Migrant Strikers. (2017). About us. Versione Italiana. Retrieved from https://berlinmigrantstrikers. noblogs.org/sample-page/about-us-italian-version

Bojadžijev, M., \& Karakayalı, S. (2007). Autonomie der Migration: 10 Thesen zu einer Methode. In Forschungsgruppe TRANSIT MIGRATION (Ed.), Kultur und soziale Praxis. Turbulente Ränder. Neue Perspektiven auf Migration an den Grenzen Europas (2nd ed., pp. 209-215). Berlin: transcript Verlag.

Bojadžijev, M., Karakayalı, S., \& Tsianos, V. (2003). Das Rätsel der Ankunft: Von Lagern und Gespenstern. Kurswechsel, 9(3), 39-52.

Buckel, S. (2013). "Welcome to Europe": Die Grenzen des europäischen Migrationsrechts. Juridische Auseinandersetzungen um das "Staatsprojekt Europa". Kultur und soziale Praxis. Bielefeld: transcript.

Bundesagentur für Arbeit. (2017). Migrations-Monitor Arbeitsmarkt: Eckwerte (Monatszahlen). Nürnberg.

Bux, U. (2017). Fact Sheets on the European Union: The citizens of the Union and their rights. Retrieved from http://www.europarl.europa.eu/atyourservice/en/ displayFtu.html?ftuld=FTU_4.1.1.html

Casas-Cortes, M., Cobarrubias, S., Genova, N. de, Garelli, G., Grappi, G., Heller, C. . . Tazzioli, M. (2014). New keywords: Migration and borders. Cultural Studies, 29(1), 55-87.

Case C-299/14 García-Nieto and Others vs. Jobcenter Kreis Recklinghausen 2016 ECLI:EU:C:2016:114.

Case C-333/13 Dano vs. Jobcenter Leipzig 2014 ECLI:EU:C:2014:2358.

Case C-67/14 Alimanovic vs. Jobcenter Berlin Neukölln 2015 ECLI:EU:C:2015:597.

Charter of Fundamental Rights of the European Union (2012) OJ 1 326/391.

Consolidated version of the Treaty on European Union (2012) OJ C 326/13.

Consolidated version of the Treaty on the Functioning of the European Union (2012) OJ C 326/47.

Curcio, A. (2013). Un coniglio aguzzino: Razza e lavoro nell'Europa della crisi. Retrieved from http://www. commonware.org/index.php/neetwork/63-un-coni glio-aguzzino 
Directive 2004/38/EC of the European Parliament and of the Council of 29 April 2004 on the right of citizens of the Union and their family members to move and reside freely within the territory of the Member States amending Regulation (EEC) No 1612/68 and repealing Directives 64/221/EEC, 68/360/EEC, 72/194/EEC, 73/148/EEC, 75/34/EEC, 75/35/EEC, 90/364/EEC, 90/365/EEC and 93/96/EEC (2004) OJ L158/77.

Faraco Blanco, C., Kraußlach, M., Montero Lange, M., \& Pfeffer-Hoffmann, C. (2015). Die Auswirkungen der Wirtschaftskrise auf die innereuropäische Arbeitsmigration am Beispiel der neuen spanischen Migration nach Deutschland (Working Paper Forschungsförderung No. 002).

Hess, S., \& Kasparek, B. (2010). Einleitung: Perspektiven kritischer Migrations- und Grenzregimeforschung. In S. Hess \& B. Kasparek (Eds.), Grenzregime: Vol. 1. Grenzregime. Diskurse, Praktiken, Institutionen in Europa (2nd ed., pp. 7-22). Berlin and Hamburg: Assoziation $A$.

Hutta, J. S., Laister, J., zur Nieden, B., \& Hess, S. (2013). Kollaborationen und GrenzGänge zwischen akademischen und nicht-akademischen Wissenspraktiken. In B. Binder, F. von Bose, K. Ebell, S. Hess, \& A. Keinz (Eds.), Eingreifen, Kritisieren, Verändern!? Interventionen ethnographisch und gendertheoretisch (pp. 151-173). Münster: Westfälisches Dampfboot.

IMIS, \& bpb. (2013). Bewegt die Krise? EU Binnenmigration und wirtschaftliche Disparitäten in Europa. Retrieved from http://www.bpb.de/gesellschaft/ migration/kurzdossiers/155391/EUbinnenmigration

İsin, E. F. (2008). Theorizing acts of citizenship. In E. F. İsin \& G. M. Nielsen (Eds.), Acts of citizenship (pp. 15-43). London and New York: Zed Books Ltd.

Jobelius, M., \& Stoiciu, V. (2014). Die Mär vom "Sozialtourismus": Zuwanderung rumänischer Staatsbürger nach Deutschland und in andere EU Mitgliedsländer. Perspektive / Friedrich-Ebert-Stiftung. Berlin: Friedrich-Ebert-Stiftung, Referat Mittel- und Osteuropa.

Kasparek, B., \& Tsianos, V. (2015). Back to the future: Blair-Schily reloaded. movements. Journal für kritische Migrations- und Grenzregimeforschung, 1(1), 1-25.

Köster-Eiserfunke, A., Reichhold, C., \& Schwiertz, H. (2014). Citizenship zwischen Status und aktivistischer Praxis: Eine Einführung. In L.-M. Heimeshoff \& S. Hess (Eds.), Grenzregime: Vol. 2. Grenzregime II. Migration, Kontrolle, Wissen. Transnationale Perspektiven (pp. 177-196). Berlin: Assoziation A.

Kötter, U. (2016). Die Entscheidung des EuGH in der Rechtssache Alimanovic: Das Ende der europäischen Sozialbürgerschaft? info also, 34(1), 3-7.

Kraußlach, M., Duschl, S., \& Pfeffer-Hoffmann, C. (2015). Ergebnisse der Studie zur Neuen Arbeitsmigration aus Spanien und Italien. In C. Pfeffer-Hoffmann (Ed.),
Profile der Neueinwanderung. Profile der Neueinwanderung. Differenzierung einer emergenten Realität der Flüchtlings- und Arbeitsmigration (pp. 59-123). Berlin: Mensch \& Buch Verlag.

Leeds Solidarity Network. (2015). The government of mobility 2: The (United) Kingdom of worfare versus welfare for migrants. Part I. Retrieved from www.con nessioniprecarie.org/2015/01/24/the-governmentof-mobility-2-the-united-kingdom-of-workfare-versus -welfare-for-migrants

Marshall, T. H. (1992). Bürgerrechte und soziale Klassen: Zur Soziologie des Wohlfahrtsstaates. Theorie und Gesellschaft: Vol. 22. Frankfurt am Main: CampusVerlag.

Marzocchi, O. (2017). Fact sheets on the European Union: Free movement of persons. Retrieved from http://www.europarl.europa.eu/atyourservice/en/ displayFtu.html?ftuld=FTU_4.1.3.html

Mayring, P. (2015). Qualitative content analysis: Theoretical background and procedures. In A. Bikner-Ahsbahs, C. Knipping, \& N. Presmeg (Eds.), Approaches to qualitative research in mathematics education (pp. 365-380). Dordrecht: Springer Netherlands.

Mezzadra, S. (2006). Diritto di fuga: Migrazioni, cittadinanza, globalizzazione. Culture: Vol. 28. Verona: Ombre Corte.

Mezzadra, S. (2007). Kapitalismus, Migrationen, Soziale Kämpfe: Vorbemerkungen zu einer Theorie der Autonomie der Migration. In M. Pieper, T. Atzert, S. Karakayalı, \& V. Tsianos (Eds.), Empire und die biopolitische Wende. Die internationale Diskussion im Anschluss an Hardt und Negri (1st ed., pp. 179-193). Frankfurt am Main: Campus-Verlag.

Mezzadra, S. (2015). The proliferation of borders and the right to escape. In Y. Jansen, R. Celikates, \& J. de Bloois (Eds.), The irregularization of migration in contemporary Europe. Detention, deportation, drowning (pp. 121-135). London: Rowman \& Littlefield.

Mezzadra, S. (2016). MLC 2015 Keynote: What's at stake in the mobility of labour? Borders, migration, contemporary capitalism. Migration, Mobility \& Displacement, 2(1), 30-43.

Mezzadra, S., \& Neilson, B. (2008). Die Grenze als Methode, oder die Vervielfältigung der Arbeit. Retrieved from http://transversal.at/transversal/0608/ mezzadraneilson/de

Mezzadra, S., \& Neilson, B. (2012). Between inclusion and exclusion: On the topology of global space and borders. Theory, Culture \& Society, 29(4/5), 58-75.

Moulier-Boutang, Y. (1998). De l'esclavage au salariat: Économie historique du salariat bridé (1st ed.). Actuel Marx confrontation. Paris: Presses Université de France.

Nicolaus, N. D. (2014). Zwischen citizenship und commoning: Recht auf Stadt in Zeiten der Eurokrise. Sub|Urban. Zeitschrift FüR Kritische Stadtforschung, 2(3), 113-125. 
Oficina Precaria Berlín. (2017). Quiénes somos. Retrieved from http://oficinaprecariaberlin.org/quienes -somos

$\varnothing$ stergaard-Nielsen, E. (2003). The politics of migrants' transnational political practices. International Migration Review, 37(3), 760-786.

Riedner, L. (2015). Justice for Janitors? Marktbürgerschaft, Freizügigkeit und EU Migrantinnen im Arbeitskampf. movements. Journal für kritische Migrationsund Grenzregimeforschung, 1(2), 1-25.

Riedner, L. (2017). Aktivierung durch Ausschluss: Sozialund migrationspolitische Transformationen unter den Bedingungen der EU Freizügigkeit. movements. Journal für kritische Migrations- und Grenzregimeforschung, 3(1), 89-108.

Rossi, U. (2013). Ascesa e crisi dell'Europa meridionale nell'era neoliberale. In Orrizonti Meridiani (Ed.), Culture: Vol. 114. Briganti o emigranti. Sud e movimenti tra conricerca e studi subalterni (pp. 39-51). Verona:
Ombre Corte.

Scheel, S. (2015). Das Konzept der Autonomie der Migration überdenken? Yes, please! movements. Journal für kritische Migrations- und Grenzregimeforschung, 1(2), 1-15.

Schoenes, K., \& Schultes, H. (2014). Was ist neu an 'neuer migration'? DISS-Journal, 28. Retrieved from https://www.diss-duisburg.de/2014/11/was-ist-nEU an-neuer-migration

Voigt, C. (2017). Ausgeschlossen oder privilegiert? Zur aufenthalts- und sozialrechtlichen Situation von Unionsbürgern und ihren Familienangehörigen. Berlin.

Walters, W. (2011). Foucault and frontiers: Notes on the birth of the humanitarian border. In U. Bröckling, S. Krasmann, \& T. Lemke (Eds.), Routledge studies in social and political thought: Vol. 71. Governmentality. Current issues and future challenges (pp. 138-164). New York: Routledge.

\section{About the Author}

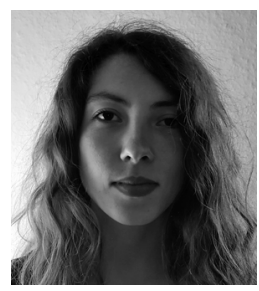

Celia Bouali is currently finishing her MA in social sciences at Humboldt University Berlin, where she also works as a student assistant at the Berlin Institute for Integration and Migration Research (BIM). In 2017, she won the university's Humboldt Award for her BA thesis on political struggles of South European migrants in Berlin in the context of EU 'migration management'. Her research interests focus on issues around labour, migration and racism. 